\title{
ANALISIS KINERJA DAN STUDI KELEMBAGAAN PASAR IKAN HIAS PARUNG, KABUPATEN BOGOR (Kasus: Ikan Cupang)
}

\author{
Cita Nabilla Thabrani*, Suharno dan Siti Jahroh \\ Magister Sains Agribisnis, Departemen Agribisnis, Fakultas Ekonomi dan Manajemen IPB \\ Institut Pertanian Bogor, Kampus IPB Dramaga, Jalan Kamper, Wing 4 Level 5 \\ Dramaga, Bogor, Indonesia 16680 \\ *Korespondensi : citanabilla@gmail.com
}

\begin{abstract}
Pasar Parung as a private market established without government interference and relying only on citizen initiatives developed into a very good market when compared to government markets that have been fully supported facilities and operations. This inequality leads to the need for evaluation in terms of market performance Parung. Parung market performance measurement is done by SCP (performance behavior structure) and Sub Terminal Agribusiness method. The market structure Parung approaches the perfect market competition structure (PPS) with a normal market share. There are 5 channels detected through Parung market. With a large margin of Rp 5645 and farmer's share of $30.46 \%$ and profit ratio of 1.49. Pasar Parung has not been able to fulfill the absolute requirement of the government's ideal market based on the concept of Sub Terminal of Agribusiness (STA), this is because the market owner is considered not having a good enough understanding in the establishment of a good market according to STA establishment standards
\end{abstract}

Keywords: Structure of Behavior and Performance, Market Parung, Ornamental Fish, Sub Terminal Agribusiness

\section{Abstrak}

Pasar Parung sebagai pasar swasta yang didirikan tanpa campur tangan pemerintah dan hanya mengandalkan inisiatif warga berkembang menjadi pasar yang sangat baik jika dibandingkan pasar pemerintah yang telah didukung penuh sarana dan operasionalnya. Ketimpangan ini menyebabkan perlu adanya evaluasi dalam hal kinerja pasar Parung. Pengukuran kinerja pasar Parung di lakukan dengan metode SCP (struktur conduct performance) dan metode analisis Sub Terminal Agribisnis. Struktur pasar Parung mendekati struktur pasar persaingan sempurna (PPS) dengan pangsa pasar yang cenderung normal. Terdapat 5 saluran yang terdeteksi melewati pasar Parung. Dengan besar margin Rp 5645 dan farmer's share $30.46 \%$ dan rasio keuntungan 1.49. Pasar Parung belum mampu memenuhi syarat mutlak pasar ideal milik pemerintah berdasarkan konsep Sub Terminal Agribisnis (STA), hal ini diakibatkan pemilik pasar dinilai belum memiliki pemahaman cukup baik dalam penentukan pasar yang baik menurut standar pendirian STA.

Kata Kunci: Struktur Perilaku dan Kinerja, Pasar Parung, Ikan Hias, Sub Terminal Agbribisnis

Cita Nabilla Thabrani, Suharno dan Siti Jahroh, 2019. Analisis Kinerja Dan Studi Kelembagaan Pasar Ikan Hias Parung, Kabupaten Bogor, JSEP 15(1): 81 - 95 


\section{Pendahuluan}

Provinsi Jawa Barat merupakan salah satu pemasok ikan hias terbesar di Indonesia (43.5\%) dari total produksi secara nasional. Dalam menyokong produksi ikan hias Indonesia, Kabupaten Bogor merupakan penyokong utama produksi ikan hias di provinsi Jawa Barat, khususnya ikan hias air tawar. Tingginya presentase peluang yang dihadapi dalam mengembangkan bisnis ikan hias, Pemerintah Kabupaten Bogor telah menetapkan sektor perikanan sebagai salah satu indikator pencapaian visi Kabupaten. Melalui peraturan daerah Kabupaten Bogor nomor 5 tahun 2014 tentang Rencana Pembangunan Jangka Menengah Daerah (RPJMD), sektor perikanan menjadi salah satu penciri Kabupaten ini.

Sebagai wujud pencapaian visi diatas, pemerintah Kabupaten Bogor menyediakan dan mendirikan beberapa fasilitas sarana dan prasarana berupa tempat penyediaan pasar sebagai pusat pengembangan dan pemasaran ikan hias. Selain itu dilakukan juga peningkatan kualitas SDM (sumber daya manusia), pengendalian mutu serta sertifikasi yang mengacu pada Standar Nasional Indonesia (SNI) sebagai standar produksi.

Beberapa pasar yang telah didirikan pemerintah Kabupaten diantaranya adalah Depo Ikan Hias Cibinong, Raiser Ikan Hias Cibinong (milik pemerintah pusat) dan yang terbaru pada tahun 2015 telah diresmikan juga pusat promosi dan pemasaran produk non konsumsi di desa Laladon Kecamatan Ciomas. Keberadaan pasar ini dijadikan pusat pengembangan dan pemasaran produk ikan hias dan diharapkan dapat dimanfaatkan sebagai sumber pendapatan masyarakat (Masrifah 2016).

Namun, besarnya dukungan pemerintah untuk meningkatkan penjualan tidak seiring dengan jumlah peminat/pembeli ikan hias di sentra-sentra yang dimaksud. Terbukti pasar yang didirikan pemerintah saat ini sepi pembeli, bahkan beberapa pedagang dipasar tersebut harus bekerja ekstra untuk mempertahankan pedagang agar tetap berjualan (Saputra 2012). Apabila permasalahan-permasalahan tersebut terus berlangsung lama maka dikhawatirkan akan menciptakan ketidakpastian dalam industri, menurunnya kapasitas produksi, menurunnya kapasitas produksi, sehingga berpengaruh terhadap efisiensi sistem pasar dan tergesernya eksistensi petani/pembudidaya (Saptana 2017). Namun hal lain tidak terjadi di Pasar yang didirikan tanpa campur tangan pemerintah dan mengandalkan inisiatif warga yaitu Pasar ikan hias Parung Kabupaten Bogor. Pasar ini tetap bertahan bahkan menjadi salah satu barometer penjualan ikan hias Indonesia (Saputra 2012).

Melihat perkembangannya hingga saat ini, tidak dapat dipungkiri bahwa pasar Parung merupakan pasar yang berkembang baik dan memiliki peran yang sangat penting fungsinya bagi perdagangan ikan hias. Banyaknya jumlah pedagang dan pembeli atau pembudidaya yang bertransaksi dipasar Parung menyebabkan timbulnya beberapa pertanyaan penting tentang proses-proses pemasaran yang terjadi dipasar ini. Aspek ini sangat penting untuk diketahui dan dievaluasi, karena bisa menjadi titik kunci dalam keberhasilan pasar dan menjadi jawaban sebagai evaluasi bagi pasar-pasar pemerintah yang kurang berjalan dengan baik.

Secara umum tujuan penelitian ini adalah melihat peran penting yang dilakukan oleh Pasar Parung sebagai salah satu mata rantai terjadinya aliran komoditi dari pembudidaya ke konsumen akhir ikan hias. Tujuan ini dilakukan 
dengan mengukur dan membandingkan kinerja pemasaran Pasar Parung dengan saluran alternatifnya serta membandingkan kebisaan pasar ini dalam memenuhi syarat mutlak terbentuknya pasar ideal milik pemerintah.

Secara umum tujuan penelitian ini adalah melihat peran penting yang dilakukan oleh Pasar Parung sebagai salah satu mata rantai terjadinya aliran komoditi dari pembudidaya ke konsumen akhir ikan hias. Tujuan ini dilakukan dengan mengukur dan membandingkan kinerja pemasaran Pasar Parung dengan saluran alternatifnya serta membandingkan kebisaan pasar ini dalam memenuhi syarat mutlak terbentuknya pasar ideal milik pemerintah

Penelitian ini hanya dipusatkan dan menggambarkan fenomena yang terjadi di pasar ikan hias Parung dan lingkungan sekitar pasar tersebut, sehingga menyebabkan hal-hal yang diidentifikasi secara khusus hanya terdapat di pasar Parung dan mungkin tidak terdapat di pasar lainnya, sehingga tidak semua pasar dapat menerapkan pola dan hasil yang telah di capai oleh pasar ikan hias Parung. Penelitian ini dibatasi oleh pembudidaya/petani produsen yang berada di wilayah sekitar Kabupaten Parung yang berprofesi sebagai pembudidaya baik sebagai mata pencaharian utama maupun mata pencaharian sampingan. Komoditas yang akan dijadikan sampel dalam penentuan efisiensi adalah Ikan cupang (Betta sp.) jantan jenis Halfmoon berukuran M (panjang baku $4 \mathrm{~cm}$ ).

\section{Metodologi}

Penelitian ini dilaksanakan di Pasar Parung, Kabupaten Bogor, Jawa Barat. Pemilihan lokasi penelitian dilakukan secara sengaja (Purposive sampling). Pemilihan tempat dilakukan dengan pertimbangan pasar tersebut merupakan pasar ikan hias terbesar di Indonesia, selain itu market yang dicapai oleh pasar ini hingga Jawa Barat, Banten, Jawa Tengah, Lampung dan Palembang. Untuk pemilihan tempat saluran pemasaran dibatasi hanya para pelaku yang berada di Kecamatan Parung. Penelitian dilapangan dilaksanakan dari bulan Februari hingga April 2017.

Komoditi ikan hias yang dipilih merupakan ikan cupang (Betta sp.), pemilihan komoditas ini didasarkan oleh jumlah pedagang terbanyak yang berjualan di pasar Parung (63 pedagang). Selain itu akses yang mudah dan adanya keterbatasan peneliti menjadi dasar pertimbangan pemilihan komoditas ini (Convenience sampling). Pada penelitian ini lembaga yang terlibat dalam pemasaran ikan cupang (Betta sp.) adalah pedagang besar yang rutin menjual ikannya di pasar Parung. Pemilihan pedagang dilakukan dengan sistem simple random sampling dan terpilih sebanyak 10 orang pedagang. Kemudian digunakan metode snowball sampling dengan mengikuti alur hingga konsumen. Metode ini akan berakhir apabila jumlah responden sudah dinyatakan cukup dalam memberikan informasi keragaan pasar.

Selain itu diperlukan wawancara mendalam tentang fungsi-fungsi pemasaran yang dijalankan di pasar Parung sebagai dasar penentuan kelengkapan sarana prasarana Sub Terminal Agribisnis dan sistem kelembagaan yang dijalankan oleh pemilik/pengelola pasar Parung untuk mengetahui pendekatan konsep yang digunakan dalam pengoperasian pasar Parung ini.

Pengolahan data yang dilakukan pada penelitian ini menggunakan analisis deskriptif yang bertujuan mengetahui secara mendalam mengenai pola sistem pemasaran yang dilakukan masing-masing lembaga pemasaran yang terlibat 
didalamnya, selain itu dilakukan juga analisis struktur dan perilaku pasar secara deskriptif. Analisis kuantitaif dilakukan untuk analisis farmer's share, analisis margin pemasaran dan analisis rasio keuntungan dan biaya pemasaran. Analisis dilakukan dengan pendekatan SCP (struktur, perilaku dan kinerja) yang akhirnya akan menghasilkan efisiensi pemasaran. Selain itu juga dilakukan analisis STA (sub terminal agribisnis) untuk mengetahui fungsi-fungsi pemasaran yang dijalankan pasar Parung jika dibandingkan dengan standar pasar ideal milik pemerintah. Pengolahan data kuantitatif menggunakan Microsoft Excel 2010.

Pelaku industri yang akan diteliti pada penelitian ini adalah para pedagang yang berjualan di pasar Parung, peneliti akan mengidentifikasi secara mendalam dan mendeskripsikan struktur pasar Parung. Adapun pengukuran yang akan di lakukan yaitu melihat pangsa pasar seperti hal nya apakah terdapat pedagang yang menonjol dibandingkan dengan pedagang lainnya di pasar Parung. Ada atau tidaknya pedagang yang lebih menonjol akan mempengaruhi konsentrasi pasar menjadi kearah monopoli ataupun ke arah pasar persaingan sempurna (PPS). Selain itu di lakukan pengamatan hambatan keluar masuk pedagang yang berjualan di pasar Parung, dengan pengamatan mekanisme pergantian pedagang yang terjadi di pasar Parung.

Perilaku pasar sentra ikan hias Parung dapat perilaku partisipan (pembeli dan penjual). Perilaku pasar dianalisis secara deskriptif yaitu menjelaskan praktek penentuan harga yang dilakukan pedagang pasar Parung, meliputi pengujian kualitas dan pemotongan harga. Selain itu perlu dilakukan pengamatan dalam praktek penjualan dan pembelian seperti mekanisme penentuan harga dan praktek negosiasi saat terjadinya transaksi. Selain itu dilakukan pengamatan ada atau tidaknya praktek kolusi antar pedagang, diskriminasi harga atau adanya praktek diferensiasi produk. Perilaku pasar ditelaah secara mendalam agar dapat menentukan kinerja pasar ikan hias Parung.

Beberapa formula penting yang digunakan dalam menganalisis keragaan pasar dilakukan dengan 3 analisis yaitu analisis marjin pemasaran, analisis farmer's share dan analisis rasio keuntungan dan biaya pemasaran.

Perjalanan suatu produk ke konsumen selalu melibatkan beberapa lembaga pemasaran sehingga marjin pemasaran total merupakan jumlah dari marjin pemasaran dari setiap lembaga pemasaran. Secara matematis dapat dirumuskan sebagai berikut:

Keterangan:

$$
M t=\sum_{t=i}^{n} M i
$$

$\mathrm{Mt}=$ Total marjin pemasaran (Rp/ekor)

$\mathrm{i} \quad=1,2,3 \ldots \mathrm{n}$

Secara matematis, marjin pemasaran dapat dinyatakan sebagai berikut (Limbong dan Sitorus, 1987):

Keterangan:

$$
\begin{gathered}
M i=P r i-P f i \\
M i=C i+\mu i
\end{gathered}
$$

$\mathrm{Mi}=$ Marjin pemasaran pada lembaga ke-i (Rp/ekor)

Pri = Harga tingkat eceran ke-i

Pfi = Harga tingkat pembudidaya ke-i 
$\mathrm{Ci} \quad=$ Biaya pemasaran yang dikeluarkan oleh lembaga ke-i

$\mu \mathrm{i} \quad=$ Keuntungan pemasaran yang diperoleh lembaga ke-i (Rp/ekor)

Farmer's Share (Bagian yang diterima Pembudidaya)

Indikator yang digunakan untuk membandingkan harga yang diterima produsen dibandingkan dengan harga yang dibayarkan oleh konsumen akhir adalah farmer's share (bagian harga yang diterima petani) yang dinyatakan dalam persentase. Secara matematis, (Limbong dan Sitorus, 1987):

Keterangan:

$$
F s=\frac{P f}{P r} x 100
$$

Fs $\quad=$ Farmer's share

Pf = Harga di tingkat produsen/pembudidaya

$\operatorname{Pr} \quad=$ Harga di tingkat konsumen

Jika harga yang ditawarkan pedagang/lembaga pemasaran semakin tinggi dan kemampuan konsumen dalam membayar semakin tinggi, maka bagian yang diterima oleh pembudidaya akan semakin sedikit. Hal ini dikarenakan pembudidaya menjual komoditasnya dengan harga yang relatif rendah. Semakin besar marjin maka penerimaan pembudidaya relatif kecil. Dengan demikian dapat diketahui adanya hubungan negatif antara marjin pemasaran dengan bagian yang diterima pembudidaya.

Rasio keuntungan dan biaya pemasaran dihitung untuk mengukur tingkat efisiensi. Apabila persebaran rasio keuntungan dan biaya pemasaran semakin merata, maka sistem pemasaran tersebut efisien. Untuk mengetahui penyebaran rasio keuntungan dan biaya pada masing-masing lembaga yang terlibat dirumuskan sebagai beikut:

Keterangan:

$$
\text { Rasio keuntungan dan biaya }=\frac{\mu}{c}
$$

$\mu$ : Keuntungan lembaga pemasaran

c : Biaya Pemasaran

Analisis ini dilakukan secara deskriptif dengan memberikan kuisioner kepada sampel. Dengan metode wawancara secara mendetail tentang fungsi-fungsi yang dijalankan meliputi fungsi pertukaran (pembelian dan penjualan), fungsi fisik (pengangkutan, penyimpanan, pengolahan dan pengemasan) dan fungsi fasilitas (stardardisasi dan grading, penanggungan resiko, dan pembiayaan).

Berupa deskripsi tentang lembaga pemasaran yang terlibat, terdiri dari pembudidaya/petani, pedagang pengumpul, pedagang besar, retailer dan konsumen.

Analisis sub terminal agribisnis diolah dengan 2 cara yaitu aspek penentuan kedalaman pengetahuan pendiri dilakukan dengan menganalisis secara deskriptif dan aspek kuantitatif dengan menghitung persenan fungsi pemasaran yang dijalankan pasar Parung lalu dibandingkan kelengkapan sarana prasarana yang ada di pasar Parung dengan sarana dan prasarana yang seharusnya tersedia di STA. Penghitungan persenan di dahulukan dengan menyediakan kuisioner berisi sarana prasarana yang sesuai dengan standar pendirian STA, selanjutnya dengan wawancara kepada pemilik pasar dilakukan mengecekan berupa menceklisan sarana 
dan prasarana yang ada dan berfungsi, ada namun tidak berfungsi, dan tidak ada. Selanjutnya masing-masing katagori di hitung berdasarkan rumus berikut:

Keterangan:

$$
\text { Persenan fasilitas }=\frac{\text { jumlah fasilitas tertentu }}{\text { jumlah keseluruhan fasilitas }} \times 100
$$

Jumlah fasilitas tertentu $=$ Di tentukan apakah fasilitas ada dan berfungsi, ada namun tidak berfungsi dan tidak ada

Kerangka Penelitian

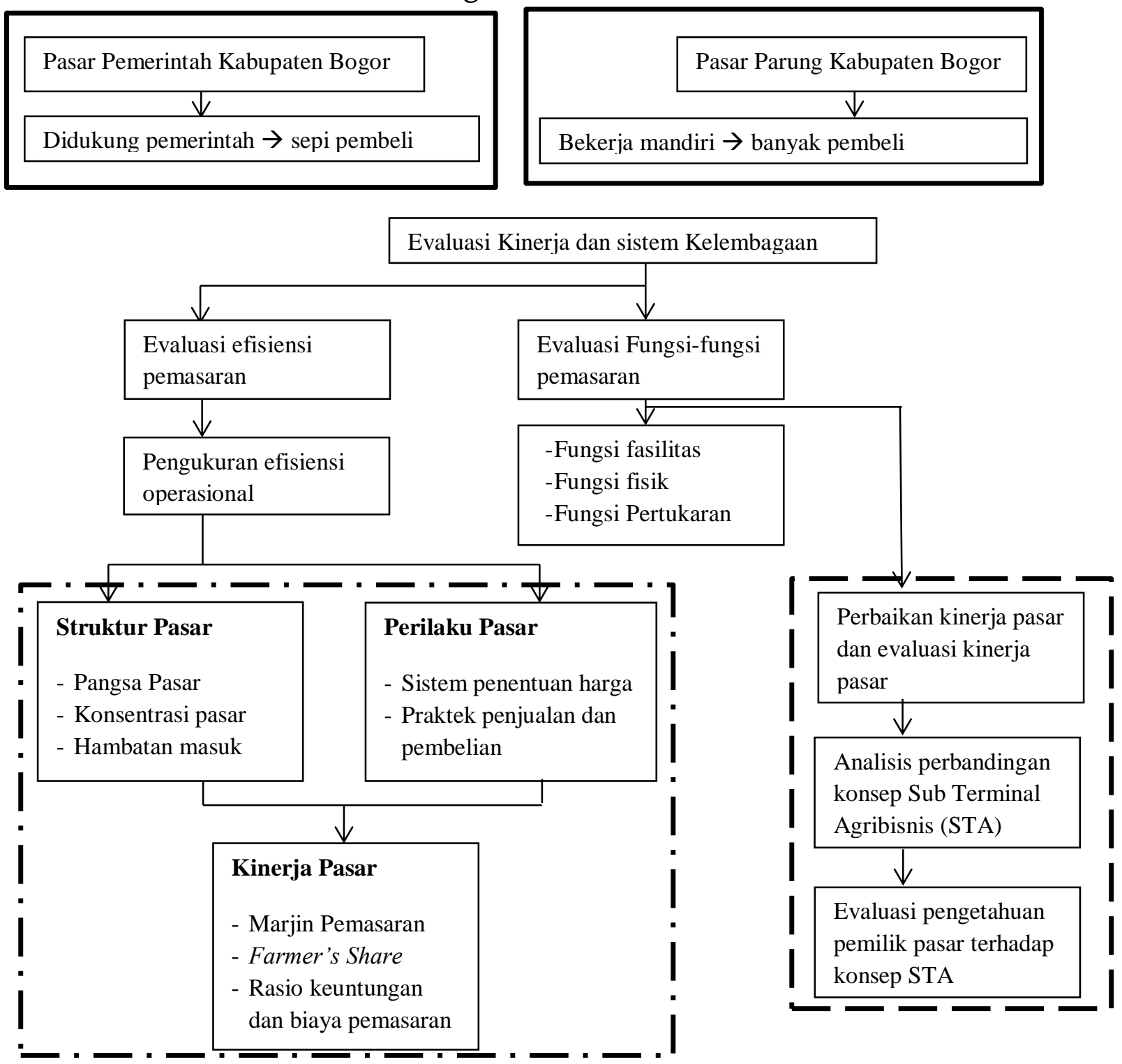

Gambar 1 Kerangka penelitian analisis kinerja pasar Parung

\section{Hasil Penelitian}

Analisis Struktur, Perilaku dan Kinerja (SCP) Pasar Parung Analisis Struktur Pasar (Market Structure) 


\section{Pangsa Pasar dan Konsentrasi Pasar}

Struktur pasar parung yang terjadi cenderung kepada pasar persaingan sempurna. Hal ini dicirikan dengan banyaknya penjual walaupun masih lebih banyak pembeli. Para pembeli bebas menentukan penjual mana yang harus dibeli dan tidak ada transaksi terikat yang menyebabkan pembeli diharuskan membeli di 1 penjual. Biasanya pembeli melakukan pembelian berulang akibat kepuasan kepada ikan yang dibeli baik dari segi kualitas maupun harga. Tidak terdapat diferensiasi bentuk penjualan ikan. Ikan yang dijual hanya dalam 1 bentuk yaitu ikan cupang segar dan hidup tanpa ada output lain. Selain itu hampir tidak ada pelaku yang lebih dominan dibanding pelaku usaha lain, satu-satunya orang yang paling dominan adalah pemilik pasar. Satu pedagang dengan pedagang lainnya tidak dapat saling mempengaruhi harga, naik turun harga hanya diakibatkan langkanya bahan baku ataupun musim. Setiap lembaga mengetahui informasi harga pasar dan terdapat harga standar untuk setiap ikan yang diperjual belikan, hanya saja masih boleh terjadinya tawar menawar harga antar penjual dan pembeli yang membeli ikan dalam jumlah besar atau merupakan langganan.

\section{Hambatan Masuk Pasar}

Di pasar parung jumlah lapak yang disediakan dibatasi oleh pemilik pasar, hal ini diakibatkan semakin tidak terkendalinya penjual yang ingin berjualan di pasar ini. Semua akses keluar dan masuk pasar ditentukan oleh pemilik pasar. Pemilik pasar memberlakukan sistem yang adil. Di awal tahun para pedagang yang menyewa lapak dikenakan tarif khusus untuk setahun kedepan, apabila para pedagang tidak melunasi pembayaran hingga waktu yang disepakati, maka pemilik pasar berhak untuk menggantikan lapak dengan pedagang lain yang ingin masuk. Pedagang yang ingin masuk juga tidak ditentukan kriterianya oleh pemilik pasar. Pemilihan hanya didasarkan kepekaan calon pedagang dalam mengetahui informasi kekosongan lapak. Orang yang mengetahui paling awal akan langsung diterima pemilik pasar tanpa syarat tertentu.

\section{Analisis Perilaku Pasar (Market Conduct)}

\section{Lembaga Pemasaran}

Lembaga pemasaran yang terlibat dalam rantai saluran yang melibatkan pasar parung meliputi pembudidaya, pedagang pengumpul kecamatan (di pasar Parung), pedagang besar, pedagang antar kota, pedagang pengecer dan eksportir.

\section{Mekanisme Penentuan Harga}

Mekanisme penentuan harga ikan cupang didasarkan dengan kualias dan ukuran ikan cupang. Semakin baik kualitasnya akan semakin tinggi harganya, begitu pula dengan ukurannya. Umumnya penentuan harga yang terjadi di pasar Parung dilakukan dengan mekanisme tawar menawar. Penentuan harga di pihak pembudidaya di awali dengan adanya harga pasar. Selain itu penentuan harga juga di akibatkan kelangkaan barang dan musim. 


\section{Sistem Pembayaran}

Sistem pembayaran yang terjadi di sepanjang saluran dilakukan dengan sistem tunai dan piutang. Sistem tunai dilakukan pedagang pengumpul kecamatan yang berada di pasar Parung maupun lembaga lainnya. Belum terdapat pembayaran dengan metode lain seperti debit dan kredit. Proses pembayaran secara piutang dilakukan oleh pembeli yang telah dipercaya oleh pedagangnya. Hal ini dikarenakan adanya kepercayaan antara kedua belah pihak tanpa adanya bukti empirik. Proses utang piutang hanya didasari rasa saling percaya kedua belah pihak yang terlibat. Hanya saja yang membatasi terjadinya proses jual beli antar satu pihak dengan yang lainnya yaitu informasi yang tidak baik.

\section{Saluran Pemasaran}

Saluran pemasaran ikan hias di pasar Parung terdiri dari pedagang pengumpul, pedagang besar, pedagang antar kota dan pedagang pengecer. Pada penelitian ini, dilakukan evaluasi juga terhadap saluran yang tidak melewati pasar Parung untuk membandingkan efisiensi pemasarannya dari segi kinerja pemasaran yaitu analisis marjin, farmer's share dan rasio keuntungan dan biaya pemasaran. Pedagang besar yang terlibat menjual ikan hias hingga luar kota dan luar provinsi seperti Palembang, Bandung dan Lampung.

Saluran pemasaran yang melewati pasar Parung terjadi melalui beberapa saluran berikut:

1. Pembudidaya - pedagang pengumpul kecamatan - pasar Parung - pedagang besar - pedagang pengecer - konsumen

2. Pembudidaya - pedagang pengumpul kecamatan - pasar Parung - pedagang pengecer - konsumen

3. Pembudidaya - pedagang pengumpul kecamatan - pasar Parung - pedagang antar kota - pedagang pengecer - konsumen

4. Pembudidaya - pedagang pengumpul kecamatan - pasar Parung - konsumen hobiis

5. Pembudidaya - pedagang pengumpul kecamatan - pasar Parung - eksportir

\section{Analisis Kinerja Pasar (Market Performance)}

\section{Analisis Fungsi Pemasaran}

Lembaga-lembaga pemasaran yang terlibat di pemasaran ikan cupang masing-masing menjalankan fungsi-fungsi pemasaran yang berbeda-beda. Pengelompokkan fungsi pemasaran menurut Limbong \& Sitorus (1987) yaitu fungsi pertukaran (pembelian dan penjualan), fungsi fisik (pengangkutan, pengemasan dan penyimpanan) dan fungsi fasilitas (sortasi, grading, penanganan resiko dan pembiayaan).

Hasil analisis fungsi pemasaran yang dilakukan, masing-masing lembaga yang terlibat di saluran pemasaran melakukan kegiatan dan fungsi-fungsi yang berbeda. Pembudidaya melakukan fungsi penjualan, sortasi, pembiayaan dan penanggungan resiko. Fungsi pengemasan terkadang dilakukan apabila terdapat perminataan dari lembaga selanjutanya. Pedagang kecamatan pasar Parung dan eksportir melakukan hampir semua fungsi pemasaran yang ada, hanya saja tidak melakukan fungsi pengolahan. Pedagang pengecer, pedagang besar dan pedagang 
antar kota melakukan fungsi yang hampir sama, hanya saja pedagang pengecer melakukan fungsi grading ulang.

Tabel 1 Fungsi pemasaran ikan cupang yang melewati pasar Parung dan yang tidak melewati pasar Parung

\begin{tabular}{|c|c|c|c|c|c|c|c|c|}
\hline \multicolumn{3}{|c|}{ Fungsi pemasaran } & \multirow{2}{*}{$\begin{array}{c}\begin{array}{c}\text { Pembudi } \\
\text { daya }\end{array} \\
-\end{array}$} & \multirow{2}{*}{$\begin{array}{c}\text { Pedaga } \\
\text { ng } \\
\text { kecama } \\
\text { tan }\end{array}$} & \multirow{2}{*}{$\begin{array}{c}\begin{array}{c}\text { Pedag } \\
\text { ang } \\
\text { besar }\end{array} \\
\frac{\sqrt{ }}{}\end{array}$} & \multirow{2}{*}{$\begin{array}{c}\text { Pedag } \\
\text { ang } \\
\text { pengec } \\
\text { er } \\
\sqrt{ }\end{array}$} & \multirow{2}{*}{$\begin{array}{l}\text { Pedaga } \\
\text { ng } \\
\text { Pengum } \\
\text { pul } \\
\sqrt{ }\end{array}$} & \multirow{2}{*}{$\begin{array}{c}\text { Pedag } \\
\text { ang } \\
\text { antar } \\
\text { kota } \\
\sqrt{ }\end{array}$} \\
\hline Pertuka & $a$ & Pombelian & & & & & & \\
\hline & $\frac{b}{b}$ & Peniualan & & $\sqrt{ }$ & $\sqrt{ }$ & $\sqrt{ }$ & $\sqrt{ }$ & $\sqrt{ }$ \\
\hline \multirow[t]{4}{*}{ Fisik } & $\mathrm{a}$ & $\begin{array}{l}\text { Pengangk } \\
\text { utan }\end{array}$ & - & $\sqrt{ }$ & $\sqrt{ }$ & $\sqrt{ }$ & $\sqrt{ }$ & $\sqrt{ }$ \\
\hline & $\mathrm{b}$ & $\begin{array}{l}\text { Penyimpa } \\
\text { nan }\end{array}$ & - & * & * & * & * & * \\
\hline & c & $\begin{array}{l}\text { Pengemas } \\
\text { an }\end{array}$ & * & $\sqrt{ }$ & * & * & * & * \\
\hline & $\mathrm{d}$ & $\begin{array}{l}\text { Pengolaha } \\
\mathrm{n}\end{array}$ & - & - & - & - & - & - \\
\hline \multirow[t]{4}{*}{ Fasilitas } & $a$ & Sortasi & $\sqrt{ }$ & $\sqrt{ }$ & - & - & - & - \\
\hline & $\mathrm{b}$ & Grading & - & $\sqrt{ }$ & - & $\sqrt{ }$ & - & - \\
\hline & $\mathrm{c}$ & $\begin{array}{l}\text { Pembiayaa } \\
\mathrm{n}\end{array}$ & $\sqrt{ }$ & $\sqrt{ }$ & $\sqrt{ }$ & $\sqrt{ }$ & $\sqrt{ }$ & $\sqrt{ }$ \\
\hline & $\mathrm{d}$ & $\begin{array}{l}\text { Penanggu } \\
\text { ngan } \\
\text { Resiko }\end{array}$ & $\sqrt{ }$ & $\sqrt{ }$ & $\sqrt{ }$ & $\sqrt{ }$ & $\sqrt{ }$ & $\sqrt{ }$ \\
\hline
\end{tabular}

Keterangan:

(-) Tidak dilakukan

( $\sqrt{ })$ Dilakukan

(*) Kadang dilakukan

Pada analisis kinerja pemasaran, saluran 4 dan 5 yang terdeteksi tidak diikutkan dalah perhitungan marjin, farmer share maupun rasio keuntungan dan biaya. Hal tersebut dikarenakan kurangnya informasi yang di dapatkan penulis akibat saluran mengarah kepada saluran pemasaran internasional. Sedangkan saluran 4 tidak diikutkan akibat saluran langsung dibeli oleh konsumen hobiis. Selain itu jumlah akses lembaga konsumen yang dapat menjangkau saluran 4 dan 5 sangatlah kecil hanya $6.5 \%$ dan $4.5 \%$ dari total seluruh saluran yang terdeteksi.

\section{Marjin Pemasaran dan Farmer's Share}

Pada analisis ini dilakukan perbandingan efisiensi operasional saluran yang melewati pasar Parung sebagai salah satu rantainya. Dan yang tidak melewati pasar Parung. Analisis marjin pemasaran dan farmer's share nya dapat dilihat pada Tabel 2 
Tabel 2 Analisis marjin pemasaran dan farmer's share

\begin{tabular}{|c|c|c|c|c|}
\hline No & Uraian & Saluran 1 & Saluran 2 & $\begin{array}{l}\text { Saluran } \\
3\end{array}$ \\
\hline \multirow[t]{3}{*}{1} & Pembudidaya & & & \\
\hline & a. Biaya Pemasaran & 90.17 & 50.08 & 95.08 \\
\hline & b. Harga Jual & 1750 & 1700 & 1775 \\
\hline \multirow[t]{6}{*}{2} & Pedagang Pengumpul & $\tan$ pasar I & & \\
\hline & a. Harga Beli & 1750 & 1700 & 1775 \\
\hline & b. Biaya Pemasaran & 169.22 & 126.43 & 104.32 \\
\hline & c. Harga Jual & 1950 & 2025 & 2012.5 \\
\hline & d. Keuntungan & 30.78 & 198.57 & 133.18 \\
\hline & e. Marjin & 200 & 325 & 237.5 \\
\hline \multirow[t]{6}{*}{3} & Pedagang Besar & & & \\
\hline & a. Harga Beli & 1950 & & \\
\hline & b. Biaya Pemasaran & 1074.62 & & \\
\hline & c. Harga Jual & 3375 & & \\
\hline & d. Keuntungan & 350.38 & & \\
\hline & e. Marjin & 1425 & & \\
\hline \multirow[t]{6}{*}{4} & Pedagang Antar Kota & & & \\
\hline & a. Harga Beli & & & 2012.5 \\
\hline & b. Biaya Pemasaran & & & 698.01 \\
\hline & c. Harga Jual & & & 4125 \\
\hline & d. Keuntungan & & & 1414.49 \\
\hline & e. Marjin & & & 2112.5 \\
\hline \multirow[t]{11}{*}{5} & Pedagang Pengecer & & & \\
\hline & a. Harga Beli & 3375 & 2025 & 4125 \\
\hline & b. Biaya Pemasaran & 878.56 & 671.10 & 691.96 \\
\hline & c. Harga Jual & 7000 & 6500 & 5645.83 \\
\hline & d. Keuntungan & 2476.44 & 3803.9 & 828.87 \\
\hline & e. Marjin & 3625 & 4475 & 1520.83 \\
\hline & Total biaya pemasaran & 2212.57 & 847.61 & 1589.37 \\
\hline & Total marjin & 5250 & 4800 & 3870.83 \\
\hline & Total marjin (\%) & 32.34 & 29.56 & 23.84 \\
\hline & Total Keuntungan & 2857.6 & 4002.47 & 2376.54 \\
\hline & Farmer's Share (\%) & 25 & 26.15 & 31.44 \\
\hline
\end{tabular}

Dari ketiga saluran yang terdeteksi dapat disimpulkan bahwa saluran 3 memiliki nilai margin terendah yaitu Rp 3870.83/ekor sedangkan margin tertinggi terdapat pada saluran 1 yaitu sebesar Rp 5250/ekor, hal ini dapat dilihat dari rantai pemasaran yang dilewati saluran 1 merupakan rantai pemasaran yang terpanjang, sehingga lembaga yang terlibat juga semakin banyak. Harga yang di keluarkan masing-masing lembaga sebenarnya cenderung homogen, dan tidak terdapat banyak perbedaan dalam treatment di masing-masing lembaga untuk lembaga lainnya, tinggi rendahnya harga akhir ditentukan oleh harga pasar. Marjin yang terdeteksi di saluran 3 diindikasikan menjadi yang terendah akibat cermatnya pedagang antar kota dalam memperhitungkan biaya masuk dan keluar. Pedagang antar kota cenderung lebih cermat akibat jauhnya jarak tempuh dan tingginya resiko yang dihadapi pedagang selama dalam perjalanan. 
Sedangkan dari analisis farmer's share didapatkan bahwa nilai farmer's share tertinggi terdeteksi berada di saluran 3 sebesar 31.44\% sedangkan nilai farmer's share terendah terdapat di saluran 1 yaitu sebesar 25\%. nilai farmer's share yang menunjukkan $\leq 50 \%$ menunjukkan bahwa harga yang dibayarkan konsumen lebih banyak menjadi bagian dari biaya dan keuntungan pedagang. Dapat dilihat bahwa farmer's share dan besar margin berbanding lurus, semakin besar margin maka semakin besar pula farmer's sharenya.

\section{Rasio Keuntungan dan Biaya Pemasaran}

Tabel 2 Rasio keuntungan dan biaya pemasaran ikan cupang

\begin{tabular}{|c|c|c|c|c|}
\hline No & Lembaga Pemasaran & $\begin{array}{c}\text { Keuntungan } \\
\text { Pemasaran } \\
\text { (Rp/ekor) }\end{array}$ & $\begin{array}{c}\text { Biaya } \\
\text { Pemasaran }\end{array}$ & $\begin{array}{c}\text { Rasio } \\
\text { Keuntungan } \\
\text { Biaya } \\
\end{array}$ \\
\hline \multirow[t]{6}{*}{1} & Saluran 1 & & & \\
\hline & a. Pembudidaya & & 90.17 & \\
\hline & b. Pedagang & 30.78 & 169.22 & 0.18 \\
\hline & Kecamatan & 350.38 & 107462 & 032 \\
\hline & c. Pedagang besar & 2476.44 & 878.56 & 2.8 \\
\hline & $\begin{array}{l}\text { d.Pedagang Pengecer } \\
\text { Total }\end{array}$ & 2857.6 & 2212.57 & 1.29 \\
\hline \multirow[t]{5}{*}{2} & Saluran 2 & & & \\
\hline & a. Pembudidaya & & 50.08 & \\
\hline & $\begin{array}{l}\text { b. Pedagang } \\
\text { Pengumnul }\end{array}$ & 198.57 & 126.43 & 1.57 \\
\hline & Kecamatan & 3803.9 & 671.1 & 5.67 \\
\hline & $\begin{array}{l}\text { c. Pedagang Pengecer } \\
\text { Total }\end{array}$ & 4002.47 & 847.61 & 4.72 \\
\hline \multirow[t]{6}{*}{3} & Saluran 3 & & & \\
\hline & a. Pembudidaya & & 95.08 & \\
\hline & $\begin{array}{l}\text { b.Pedagang } \\
\text { Pengumpul }\end{array}$ & 133.18 & 104.32 & 1.27 \\
\hline & Kecamatan & 1414.49 & 698.01 & 2.02 \\
\hline & c. Pedagang antar kota & 828.87 & 691.96 & 1.19 \\
\hline & $\begin{array}{l}\text { d.Pedagang pengecer } \\
\text { Total }\end{array}$ & 2376.54 & 1589.37 & 1.49 \\
\hline
\end{tabular}

Nilai efisiensi dapat didekati dengan membandingkan output pemasaran terhadap inputnya (Sudiyono 2002), nilai R/C rasio yang $>1$ menunjukkan bahwa kegiatan pemasaran yang dilakukan mendapatkan keuntungan. Meratanya penyebaran rasio keuntungan dan biaya marjin pemasaran terhadap biaya pemasaran, maka secara teknis sistem pemasaran tersebut semakin efisien. Dari 3 saluran yang diperhitungkan hasil analisis menunjukkan bahwa rasio keuntungan dan biaya pemasaran yang paling merata terdapat pada saluran 3, yaitu sebesar 1.49.

Jika dibandingkan dengan menggunakan pendekatan marjin dan farmer's share, saluran 3 memiliki nilai margin sebesar Rp 3870.83 dan farmer's share sebesar 
31.44\%. Efisiensi dapat ditentukan dengan semakin rendahnya nilai margin dan semakin tingginya farmer's share selain itu juga ditentukan dengan semakin meratanya nilai keuntungan rasio. Berdasarkan data tersebut dapat disimpulkan bahwa saluran 3 menjadi saluran paling efisien, selain itu meratanya penyebaran rasio keuntungan di seluruh lembaga yang terlibat menjadi titik penting dalam saluran yang efisien.

\section{Analisis Market Place atau Pasar Fisik}

\section{Analisis Sub Terminal Agribisnis (STA) Analisis Kelengkapan Sarana Prasarana Pasar Parung}

Pasar Parung menurut karakteristiknya merupakan tempat transaksi jual beli hasil-hasil pertanian berupa ikan hias yang terletak di sentra produksi sebagai mana Sub Terminal Agribisnis, perbedaan yang nyata terdapat pada sejarah pendirian pasar Parung yang merupakan pasar swasta yang didirikan oleh pribadi dan bukan oleh pemerintah. Kesamaan tersebut mendorong keingintahuan kinerja pasar Parung jika dibandingkan dengan STA, hal-hal yang menjadi syarat mutlak didirikannya STA adalah adanya sarana dan prasarana pendukung berjalannya fungsi-fungsi pemasaran di pasar Parung. Berdasarkan pedoman pendirian Sub Terminal Agribisnis sarana dan prasarana yang mutlak ada di STA adalah seperti pada Tabel 4.

Berdasarkan data diatas dapat diketahui bahwa hanya $42.5 \%$ sarana dan prasarana sub terminal agribisnis yang ada dan berfungsi dengan di pasar Parung, sedangkan 10\% lainnya tersedia namun tidak berfungsi. Hal ini menunjukkan bahwa fungsi-fungsi pemasaran tidak terjadi langsung di pasar Parung, pasar parung hanya menjadi tempat transaksi jual beli dan bongkar muat produk ikan hias, sebagian fungsi pemasaran yang seharusnya terjadi di pasar, tidak dilakukan di pasar ini.

Tidak terdapat fasilitas fax, semua komunikasi dilakukan via telepon dengan perjanjian sebelumnya, pembeli yang paling banyak merupakan pedagang sehingga tau persis pedagang yang berjualan di pasar Parung, fasilitas operator dan informasi tidak tersedia di pasar ini, semua pedagang menjual dagangannya dengan menggunakan plastik packing dan di susun di lapak. Fasilitas internet juga tidak di maksimalkan, rata-rata pembeli mengetahui dan mempromosikan pasar Parung dari mulut ke mulut, namun saat ini sudah banyak pihak ketiga yang mempromosikan pasar Parung di media internet seperti media cetak maupun elektronik.

Ruang promosi, display maupun tempat peragaan contoh produk tidak terdapat di pasar ini, semua pembeli menggunakan metode konvensional seperti di pasar pada umumnya, proses tawar menawar dan transaksi jual beli dilakukan di masing-masing lapak, begitupun melihat kualitas ikan dan menanyakan informasi ikan tersebut dilakukan langsung dengan penjual.

Sarana grading dan sortasi dilakukan para pedagang sendiri di kediaman masing-masing, sebagian lainnya dilakukan oleh pembudidaya. Sarana lainnya seperti gudang, cool room ataupun tempat packing tidak disediakan di pasar parung, masing-masing pedagang membawa kembali ikan hias yang tidak laku terjual di hari tersebut, dan me re-packing di kediaman masing-masing. Pembinaan mutu produk tidak dilakukan, hanya didasari dengan kejujuran dan rasa persaingan antar pedagang, persaingan yang terjadi juga sangat baik karena pedagang harus terus menjaga kualitas barangnya agar tidak ditinggalkan konsumen, selain itu 
pengujian mutu produk dilakukan oleh masing-masing pembeli secara sepintas, lebih mengandalkan insting dan kepercayaan antar penjual dan pembeli, ikan yang kualitasnya baik biasanya di cirikan dengan kelincahan dan warnanya yang menarik.

Tabel 4 Sarana dan Prasarana yang Tersedia di Pasar Parung menurut pedoman Sub Terminal Agribisnis

\begin{tabular}{|c|c|c|c|c|}
\hline Nomor & Sarana/Prasarana & $\begin{array}{c}\text { Ada } \\
\text { Berfungsi }\end{array}$ & $\begin{array}{l}\text { Ada, Tidak } \\
\text { Berfungsi }\end{array}$ & Tidak Ada \\
\hline \multirow[t]{7}{*}{1} & $\begin{array}{l}\text { Tempat transaksi sesuai cara } \\
\text { transaksinya }\end{array}$ & & & \\
\hline & a. Kantor administrasi & $\sqrt{ }$ & & \\
\hline & b. Kantor keuangan (kasir) & $\sqrt{ }$ & & \\
\hline & c. Timbangan & & & $\sqrt{ }$ \\
\hline & d. Keranjang (plastik packing) & $\sqrt{ }$ & & \\
\hline & e. Box & & & $\sqrt{ }$ \\
\hline & f. Tempat bongkar muat & $\sqrt{ }$ & & \\
\hline \multirow[t]{5}{*}{2} & Distribusi & & & \\
\hline & a. Sarana transportasi & $\sqrt{ }$ & & \\
\hline & b. Gudang & & & $\sqrt{ }$ \\
\hline & c. Cool room & & & $\sqrt{ }$ \\
\hline & d. Keranjang box (tempat packing) & & $\sqrt{ }$ & \\
\hline \multirow[t]{5}{*}{3} & Komunikasi dan informasi & & & \\
\hline & a. Telpon & $\sqrt{ }$ & & \\
\hline & b. Fax & & & $\sqrt{ }$ \\
\hline & c. Operator & & & $\sqrt{ }$ \\
\hline & d. Internet & & $\sqrt{ }$ & \\
\hline
\end{tabular}

$4 \quad$ Promosi
a. Ruang promosi
b. Display
c. Tempat keragaan produk

$5 \quad$ Peningkatan jaminan mutu
a. Sanitasi
b. Air bersih
c. Tempat dan sarana sortasi
d. Tempat grading
e. Tempat pengemasan
f. Pembinaan mutu produk
g. Pengujian mutu produk
h. Penjagaan keamanan

6 Sarana pendukung lainnya
a. Aerasi*
b. Penyediaan saproduksi
c. Oksigenasi*
d. Rumah makan/kios
e. Penginapan/tempat istirahat
f. Kebersihan lingkungan
g. Lembaga keuangan
h. Rumah ibadah
i. Mesin ATM
j. Bank 
Penginapan dan tempat istirahat tidak tersedia di pasar Parung, hal tersebut dikarenakan pembeli yang datang akan langsung membawa pulang barang nya, bagi pembeli yang datang dari luar kota atau daerah biasanya memesan terlebih dahulu ikan yang akan dibelinya pada beberapa hari sebelumnya, dan datang hanya mengambil barang dan melakukan proses pembayaran, proses tawar menawar juga dilakukan melalui telepon. Mesin ATM terdapat diluar pasar, namun lokasi ATM yang tidak terlalu jauh dapat diantisipasi pembeli, namun bagi pedagang terkadang memiliki kesulitan dalam menyetor uang yang diterima, karena semua penjualan yang terjadi di pasar Parung masih konvensional, tidak ada cara pembayaran lain kecuali cash sehingga keberadaan bank sangat diperlukan.

Rendahnya tingkat pemenuhan sarana dan prasarana yang terdapat di pasar Parung menunjukkan bahwa pasar tersebut belum dapat memenuhi kriteria pendirian STA. Hal tersebut juga menunjukkan bahwa pasar swasta yang dibangun oleh pola swakarsa masyarakat belum mampu memaksimumkan efisiensi pemasaran yang dijalankan, sehingga seharusnya harga yang ditawarkan bisa lebih rendah dari yang sudah ada. Pendiri pasar belum mampu mencanangkan konsep STA di pasar Parung, dan belum memiliki pengetahuan yang cukup dalam memaksimumkan efisiensi pemasaran yang dijalankan di pasar Parung.

\section{Kesimpulan}

(1) Analisis struktur pasar Parung mendekati struktur persaingan sempurna. Pangsa terbesar pedagang yang terlibat di pasar Parung yaitu pedagang besar dengan pangsa $>65 \%$ dari keseluruhan pedagang ikan cupang. Kebanyakan harga yang terjadi merupakan harga Pasar yang dipengaruhi ketersediaan barang dan musim. (2) Analisis perilaku pasar di bagi menjadi beberapa bagian. Lembaga pemasaran yang terlibat pada saluran yang melewati pasar Parung yaitu pedagang pengumpul kecamatan, pedagang besar, pedagang antar kota, pedagang pengecer dan eksportir. Sistem pembayaran yang terjadi di pasar Parung adalah tunai dan piutang. Terdapat 5 saluran pemasaran ikan cupang (Betta sp.) yang terdeteksi.

(3)Analisi kinerja pasar berdasarkan analisis margin, farmer's share dan sebaran rasio keuntungan menunjukkan saluran yang paling efisien merupakan saluran 3 dengan sebaran margin Rp 5645 dan farmer's share 30.46\% dan rasio keuntungan 1.49.

(4) Pasar Parung belum mampu memenuhi syarat mutlak pasar ideal milik pemerintah berdasarkan konsep Sub Terminal Agribisnis (STA), hal ini dinilai akibat pemilik pasar belum memiliki pemahaman yang cukup memiliki pemahaman yang cukup luas dalam menentukan pasar yang baik menurut standar pendirian STA. Perlu dilakukan penghitungan efisiensi pemasaran di sektor pasar pemerintah untuk bahan perbandingan lanjutan. Efisiensi pemasaran di pasar Parung dapat ditingkatkan dengan pemenuhan sarana dan prasarana berdasarkan konsep Sub Terminal Agribisnis (STA).

\section{Daftar Pustaka}

Limbong, W.H. dan P. Sitorus. 1987. Pengantar Tataniaga Pertanian. Jurusan Ilmu-Ilmu Sosial Ekonomi Pertanian, Fakultas Pertanian, Bogor: IPB Press 
Masrifah E. 2016. Meningkatkan Perekonomian Masyarakat Melalui Budidaya Ikan Hias yang Berdaya Saing. http:/ / disnakan. Bogorkab.go.id [23 April 2017]

Saputra E. 2012. Sentra Ikan Hias Parung: Terbesar di Indonesia, editorial. Kontan.co.id [internet] waktu unduh [2010 Juni 06].

Saputra E. 2016. Sentra Ikan Hias Parung Tetap Bertahan, editor. http://peluangusaha.kontan.co.id [22 Februari 2016].

Saptana et al. 2017. Produksi dan Pemasaran Komoditas Broiler di Jawa Barat. Jurnal Manajemen \& Agribisnis. 14(2):152-164

Sudiyono A. 2002. Pemasaran Pertanian. Malang (ID): Universitas Muhammadiyah Malang. 